\title{
Traumatic Floating Bone. About 11 Cases and a Literature Review
}

\author{
Amadou Ndiassé Kasse ${ }^{1 *}$, Malick Diallo², Souleymane Diao'1, Jean Claude Sane1, \\ Abdoulaye Bousso ${ }^{3}$, Abdou Razack Ndiaye ${ }^{3}$, Mouhamadou Habib SY${ }^{1}$ \\ ${ }^{1}$ University of Dakar, Dakar, Senegal \\ ${ }^{2}$ University of Bobo-Dioulasso, Bobo-Dioulasso, Burkina Faso \\ ${ }^{3}$ Hôpital Général de Grand-Yoff, Dakar, Senegal \\ Email: *amadoukasse@hotmail.com
}

How to cite this paper: Kasse, A.N. Diallo, M., Diao, S., Sane, J.C., Bousso, A., Ndiaye, A.R. and SY, M.H. (2017) Traumatic Floating Bone. About 11 Cases and a Literature Review. Open Journal of Orthopedics, 7, 383-395.

https://doi.org/10.4236/ojo.2017.712040

Received: October 7, 2017

Accepted: November 27, 2017

Published: November 30, 2017

Copyright (C) 2017 by authors and Scientific Research Publishing Inc. This work is licensed under the Creative Commons Attribution International License (CC BY 4.0).

http://creativecommons.org/licenses/by/4.0/

\begin{abstract}
Introduction: Floating bone injury or bipolar dislocation is a concurrent dislocation at both ends of a long bone or a flat bone. It is an exceptional injury. We report 11 consecutives cases of floating bones. Objectives: The aim of the study is to analyze the frequency, the mechanism of injury and clinical forms of floating bones, and to present the results of their management. Material and Methods: A ten years ongoing retrospective study was held in four trauma departments. Eleven cases of floating bones were identified. The floating bones characteristics such as the injured bone, the patient age and sex, the mechanism of injury, the dislocations directions, the associated complications, the treatment and the outcome were studied. Results: Nine male and two female patients, with a mean age of 37 years [19 - 65 years range] presented a concurrent bipolar dislocation of one bone or a group of bones. They sustained a road traffic accident $(n=5)$, a workplace accident ( $\mathrm{n}$ $=3)$, a fall from height $(\mathrm{n}=2)$, and a sport accident $(\mathrm{n}=1)$. The clavicle $(\mathrm{n}=$ 3 ) and the first metatarsal $(n=3)$ were the most frequently involved. The others floating bones were the radius-ulna complex $(\mathrm{n}=1)$, the radius-lunatum complex $(\mathrm{n}=1)$, the first metacarpal $(\mathrm{n}=1)$, the first phalanx $(\mathrm{n}=1)$ and the femur $(\mathrm{n}=1)$. The floating bones ends displacement occurred in the sagittal plane (the forearm, the femur, the first phalanx and the first metatarsal) and in the horizontal plane (the clavicle, the first metatarsal and the first metacarpal). We defined direction displacements as bidirectional asymmetric $(\mathrm{n}=10)$ or unidirectional symmetric $(\mathrm{n}=1)$. Associated complications were fractures (wrist, hip, tarso-metatarsal joints) and wounds (fingers, metatarso-phalangeal joint). Dislocations were treated conservatively $(n=5)$ and surgically $(n=17)$ with excellent results $(n=13 / 16$ joints). Three patients were lost of view. Conclusion: Our study described the characteristics of
\end{abstract}


this exceptional injury. For any joint dislocation, we promote the systematic examination of the other end of the dislocated bone.

\section{Keywords}

Traumatic Dislocation, Floating Bone, Bipolar Dislocation, Clavicle, First Metatarsal, Forearm, First Metacarpal, First Phalanx, Femur

\section{Introduction}

The bipolar dislocation is permanent displacements of a long bone or a flat bone from their two ends joint. This two-side dislocation occurs as a one-time injury [1] [2] [3] or two-time injury [4] [5]. The isolated bone is so called a "floating bone" [2] [5] [6]. It is an exceptional injury usually published as case report [1]-[34].

The aim of our study was to study the frequency, the mechanism of injury, and the clinical presentations and to report results of orthopedic and/or surgical treatment.

\section{Patients and Methods}

A ten years (March 2003 to February 2012) ongoing multicentric retrospective study was held in trauma departments of four Senegalese hospitals (One University teaching hospital in the capital and three regional hospitals).

Eleven cases were identified:

- Eight cases were found among 102,511 trauma cases and among 2369 dislocations cases at the trauma department of the University teaching hospital of Grand Yoff in Dakar;

- The others cases were found at the trauma departments of Regional Hospitals of Thiès $(n=1)$, Kaolack $(n=1)$ and Tambacounda $(n=1)$. The total of dislocations cases in these regional hospitals was unavailable.

The studied variables were the injured bone, the patient age and sex, the mechanism of injury (MOI), the dislocations directions, the associated complications, the treatment and the outcome.

\section{Results}

\subsection{Epidemiology}

The mean age at the trauma time was 37 years [19 - 65] and the male to female ratio was 5.5:1. The floating bones represented $0.007 \%$ of trauma cases and $0.3 \%$ of dislocations cases.

\subsection{Mechanism of Injury (MOI)}

The main MOI was a high velocity axial load $(n=9)$ during traffic accidents $(n=$ $5)$, falls from height $(n=2)$ and workplace accidents $(n=2)$. The others 
circumstances were a simple fall on a sport field $(\mathrm{n}=1)$ and on a workplace $(\mathrm{n}=$ 1). The exact mechanism remained unclear but we retained an indirect mechanism with a successive dislocation.

\subsection{Clinical Presentations and Complications}

The dislocations were occurred in the sagittal plane $(\mathrm{n}=6)$ or in the horizontal plane $(n=5)$. The direction of two dislocations was unidirectional and symmetric in the case of floating first phalanx of the second finger. It was bidirectional crossed and asymmetric in the other cases $(n=10)$.

The more dislocated bones were the clavicle $(\mathrm{n}=3)$ and the first metatarsal ( $\mathrm{n}$ $=3)$. The femur $(n=1)$, the radius-ulna complex $(n=1)$, the radius-ulnalunatum complex $(\mathrm{n}=1)$, the first metacarpal $(\mathrm{n}=1)$ and the first phalanx of the second finger $(\mathrm{n}=1)$ were less touched (Figure 1$)$.

The floating clavicle displacement was regularly bidirectional asymmetric crossed with a postero-superior displacement of its acromial end and an antero-inferior displacement of its sternal end (Figure 2).

The floating metatarsal displacement was diversified. Its tarsal end was displaced inward with a fracture of the second metatarsal $(\mathrm{n}=2)$ (medial cuneometatarsal joint medial dislocation) or upward $(\mathrm{n}=1)$ (medial cuneometatarsal joint dorsal dislocation). Its phalangeal end was still displaced downward $(n=1)$ (first metatarsophalangeal joint dorsal dislocation) or outward and downward $(\mathrm{n}=2)$ (first metatarsophalangeal joint dorsolateral dislocation) with respect of the sesamoid bones (Figure 3).

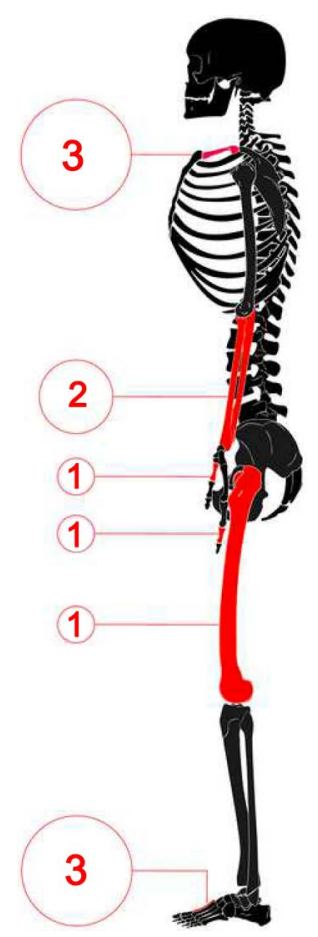

Figure 1. Floating bones topography distribution. Number of case in circle (courtesy of Malick Diallo). 


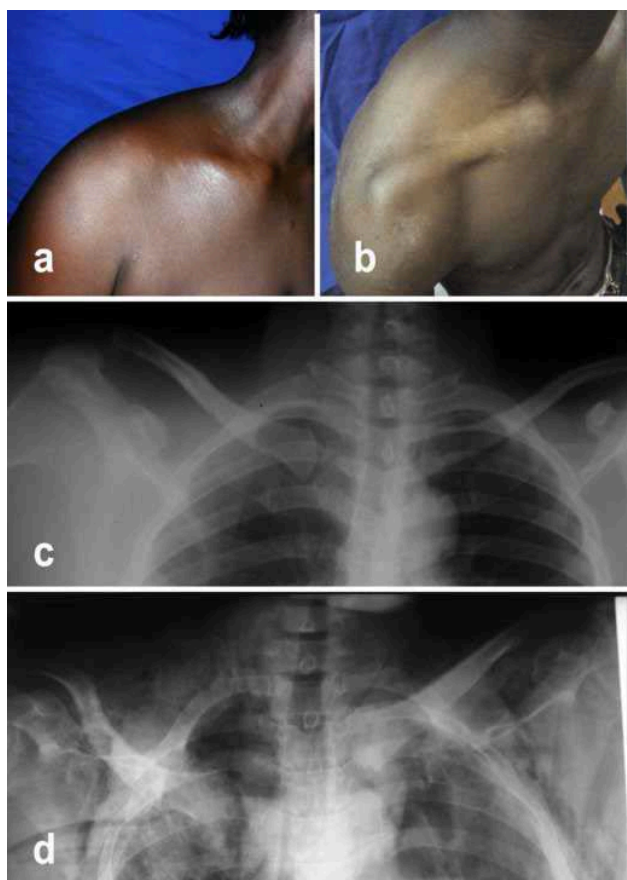

Figure 2. Floating clavicles. ((a) and (b)): Clinical presentations showing a floating right clavicle in a 40 years-old female (Case No. 3) and a floating right clavicle in a 19 years-old male (Case No. 2) respectively. (c) AP view of a thorax grid showing a right floating clavicle (Case No. 3). (d) AP view of a thorax grid showing a left floating clavicle (Case No. 2).
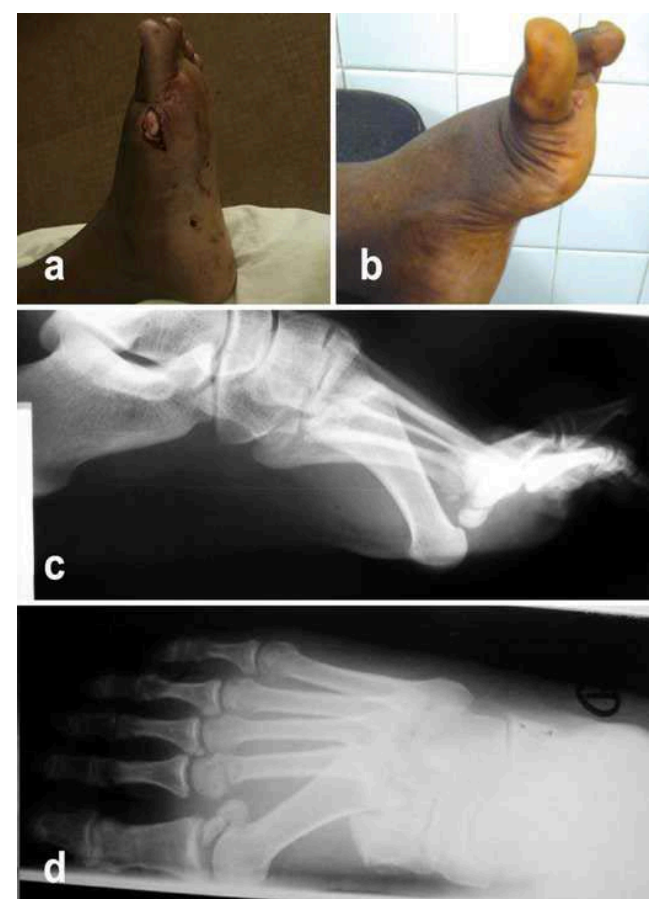

Figure 3. Floating first metatarsals. (a) Clinical presentation. Medio-laterally displaced floating left first metatarsal with the head of the first metatarsal herniated through a wound on the medial side of the foot (Case No. 5). (b) Clinical presentation. Dorsoplantarly displaced floating left first metatarsal with a sagittal Z deformity (Case No. 4). (c) Lateral view of a foot showing an asymmetric floating first metatarsal (Case No. 4). (d) AP view of a right foot showing an asymmetric floating first metatarsal (Case No. 6). 
The floating forearm displacement was bidirectional crossed and asymmetric. Its humeral end was displaced postero-laterally (elbow-joint posterolateral dislocation) and its carpal end was displaced antero-medially (posterolateral radiocarpal dislocation associated to a complex distal radius fracture and posterolateral perilunate dislocation) (Figures 4(a)-(c)). The floating femur displacement was bidirectional crossed and asymmetric. Its iliac end was displaced backward and upward (posterosuperior hip-joint dislocation with an associated fracture of the posterior wall of the acetabulum) and its tibial end was displaced frontward (posterior knee-joint dislocation) (Figure 4(d) and Figure 4(e)). The floating first metacarpal displacement was bidirectional crossed and asymmetric. Its trapezial end was displaced backward and outward (posterolateral trapeziometacarpal joint dislocation) and its phalangeal end was displaced frontward (posterior inter-phalangeal joint dislocation of the thumb (Figure 5(a) and Figure 5(b)). The floating first phalanx of the second finger displacement was unidirectional and symmetric. Its metacarpal and phalangeal ends were displaced backward (posterior metacarpophalangeal joint dislocation and anterior proximal inter-phalangeal joint dislocation of the third finger) (Figure 5(c) and Figure 5(d)).

It was four open dislocations (hand and foot) and two fractures (the acetabulum and the second metatarsal bone).

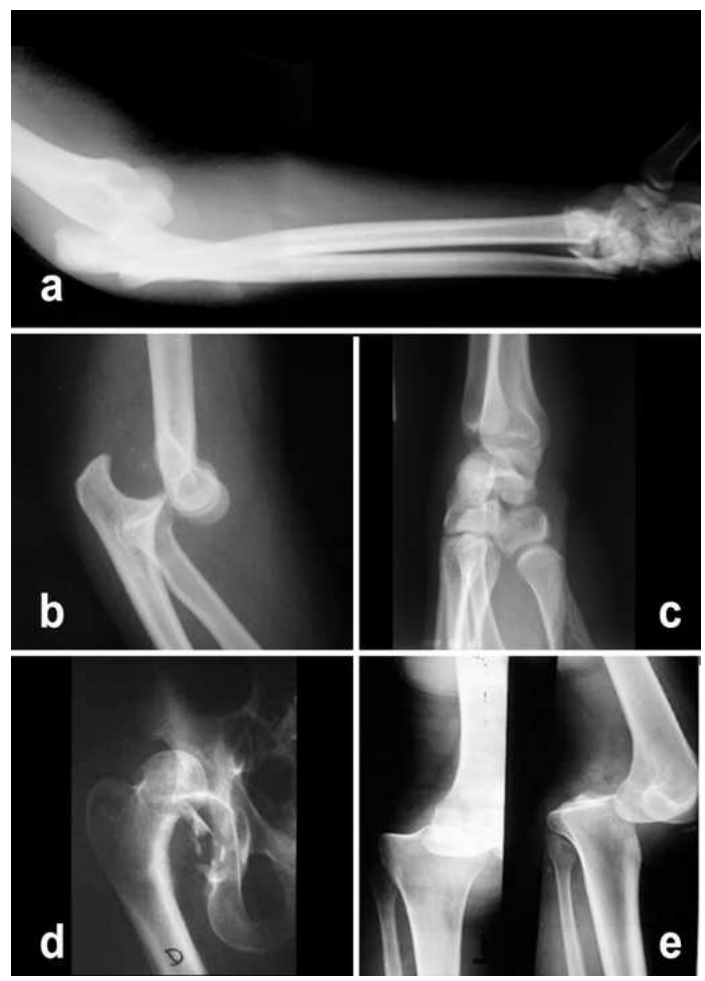

Figure 4. Floating forearms and a floating femur. (a) Lateral view showing an asymmetric floating radio-ulnar complex with an associated fracture of the distal radius (Case No. 7). ((b) and (c)): Lateral views of a left elbow and wrist showing respectively a posterior elbow and a perilunate dislocation (Case No. 8). ((d) and (e)): A Pelvic and a right Knee AP views showing respectively a posterior hip fracture-dislocation and a posterolateral knee dislocation (Case No. 9). 

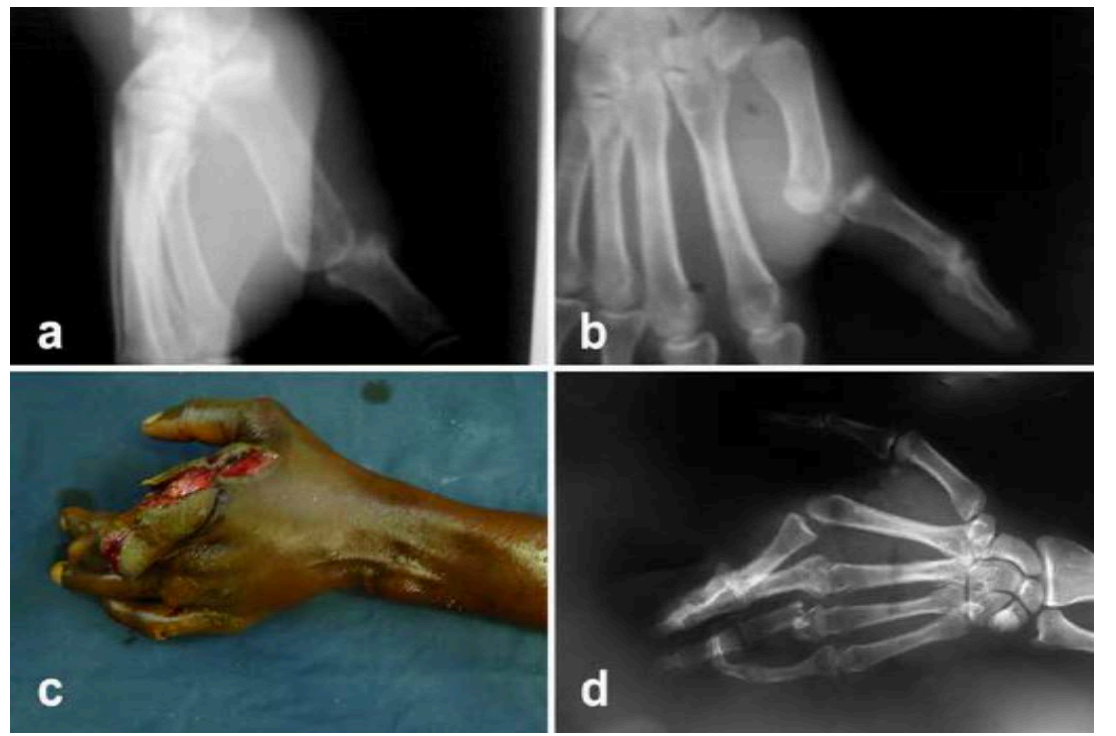

Figure 5. A floating first metacarpal and a floating first phalanx. ((a) and (b)): AP and Lateral view of a left thumb showing an asymmetric floating first metacarpal (Case No. 10). ((c) and (d)): Clinical presentation and an AP view of a left hand showing an asymmetric floating first phalanx of the second finger (Case No. 11).

\subsection{Treatment and Outcome}

All joints dislocations were reduced in emergency with or without anesthesia. We chose to reduce the distal joint before the proximal joint. Closed reductions by external manoeuver were performed for the femur (knee and hip), for the forearm (two-times on the elbow-joint and one-time for the perilunate dislocation) and for the first metatarsal (one-time for the cuneo-metatarsal joint). The closed reduction of the femur was followed by three weeks transosseous traction. In the other cases (the clavicles, the remaining first metatarsals, the first metacarpal and the first phalanx of the index), open reductions were performed (Figure 6). Surgical reductions focused sesamoids incarceration (metacarpophalangeal joint), ligaments reparation (hand and foot) and temporally internal fixations. Non absorbable trans-osseous sutures and four to six week pinning was used as internal fixation methods. One ligamentotaxis exofixation was used for the wrist fracture dislocation.

Closed reduction cases gave good results with two exceptions. The hip fracture dislocation and the knee dislocation were unstable. Open reduction and internal fixation cases with pins removal at $4-6$ weeks did not presented residual instabilities.

Nine patients were monitored with 19 months mean follow up time (3 months to 6 years). Three patients were lost of view (the floating first phalanx, the floating first metacarpal and the floating radius-lunatum complex). Functional results were excellent in 13 joints. It was two fair functional results (Hip and wrist). They presented a wrist reflex sympathetic dystrophy and a hip post traumatic arthritis. The knee dislocation outcome was poor with a chronic instability and osteoarthritis. 


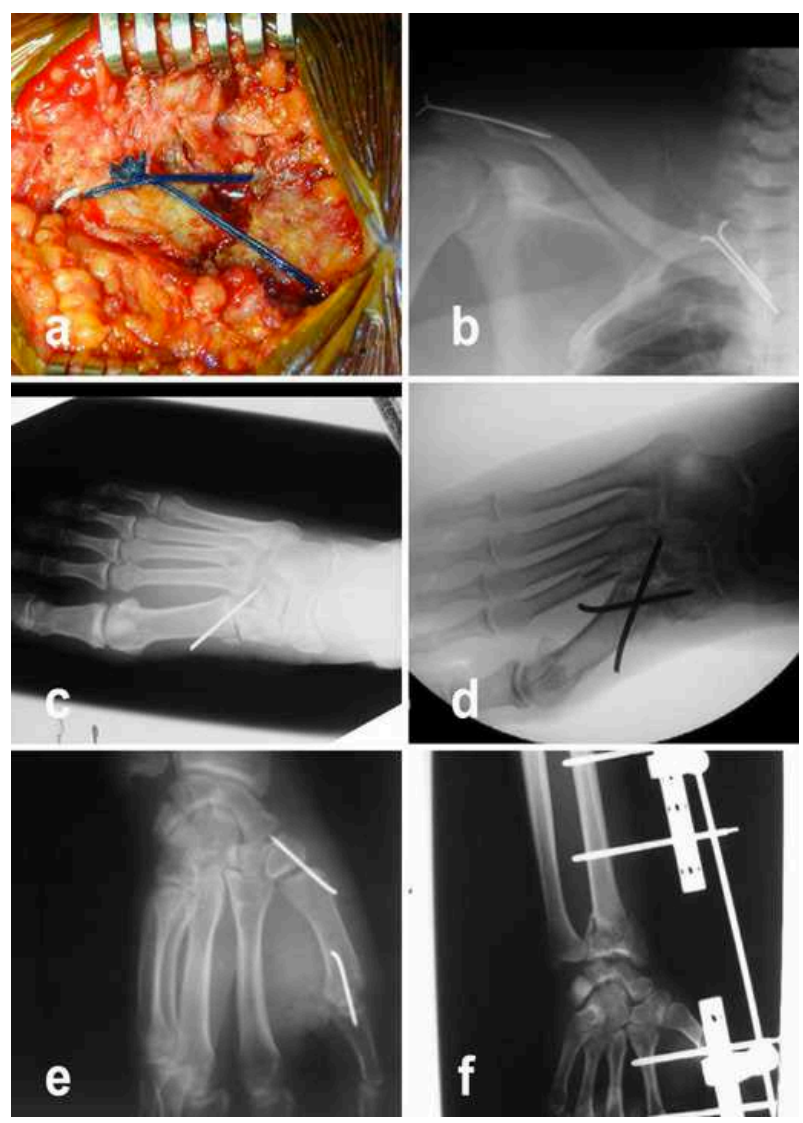

Figure 6. Surgical treatment of a floating clavicle ((a) and (b)), a floating first metatarsal $((c)$ and $(d))$, a floating first phalanx (e) and a floating forearm (f).

\section{Discussion}

This retrospective study have some limits linked to the numbers of patients despite the long observationnal period. The rarety of this lesions and its exceptional report in literature give to this case serie a certain value to be commented.

\subsection{Nosology}

The complete dislocation of a long or a flat bone at their two ends frees the bone and makes it "floating".

Porral [9] in 1831 first describe this injury on a clavicle and Jain [5] called it a "floating clavicle" in 1984. By analogy with the clavicle, Liebner [6] described the "floating first metatarsal" in 1997. Many other names were also used to name this rare injury: "coupled dislocation" [35], "pan-disclocation" [4], "double dislocation" [5] and "bipolar dislocation" [8]. Whenever, this injury might be distinguished from "a floating joint" which means fractures above and below a joint [36].

\subsection{Epidemiology}

Traumatic floating bones are exceptional injuries. The most injured bones could 
be divided in three groups. The first group with a true freed long bone includes the clavicle [3] [5] [9], the first metatarsal [6] [9] [13] [35], the femur [17] [34], the humerus [18] [32], the first metacarpal [19], the firth metacarpal [20], the second metacarpal [21], the third metacarpal [22], the fourth metacarpal [35], the fifth metatarsal [35], the isolated ulna [23], the fibula [24], the first phalanx [25], the second phalanx [26], etc. The second group with a freed group of bones includes the forearm (radius-ulna complex [27] [28] or radius- ulna-lunatum complex [15] [29] and the leg (tibia-fibula-talus complex) [30]. The third group with a true freed flat bone included the ilium [31].

\subsection{Mechanism of Injury}

Three conditions are necessary to produce a floating bone: a high energy trauma, a strong bones and a suitable position. The position determinate the anatomical form. Motor vehicle accidents [3] [4] [7] [8] [10] [11] [12] [13] [16] [17] [18] [20] [27] [29] [34] and falls from height [2] [14] [15] [19] [21] [25] [26] [28] [30] [32] are commonly reported. Two main theories were evocated: the simultaneous theory [1] [2] [3] and the successive theory [4] [5].

The successive dislocations theory: on the upper and lower limb, mechanical constraints in forced hyper-flexion and axial load dislocate firstly the distal joint. Then, the distal end act as fulcrum and the dislocation of the proximal end occurs. The muscular insertion determinates displacements directions. Sometimes, compressions or twisted constraints are present. On scapular and pelvic grid, constrains are compressions and axial loads. We think that the associated constrains in flexion and compression and the twisted constraints create bidirectional crossed asymmetric dislocations.

The simultaneous dislocations theory: compressions constraints are absorbed by a solid bone as a deforming energy.

Then, the bone finds back its normal form by transferring this deforming energy to its ends and frees itself from its joints attachments [3]. This might explain the unidirectional symmetric displacement.

\subsection{Clinical Presentations}

\subsubsection{Anatomy}

To avoid confusion, we consider displacements of the floating bone ends and not joint displacements. So, a dislocation on a floating bone distal end has an inverted direction of this distal joint dislocation. In the unidirectional symmetric dislocations, the two ends of a floating bone have a same dislocation direction. In the bidirectional asymmetric dislocations, the two ends of a floating bone have an opposed dislocation direction. The bidirectional asymmetric dislocation was more reported in literature [1] [3]-[8] [11] [13] [14] [15] [16] [19] [21] [22] [27] [28] [29] [30] [33]. The unidirectional symmetric dislocation was reported in the floating humerus [18] [32] and in the floating femurs [17] [34]. The clinical examination of the floating long bones demonstrates a " $Z$ deformity": a "Transverse Z" deformity for the clavicle and a "Sagittal Z" for the other longs 
bones (arm, forearm, fingers, thigh, leg and foot).

\subsubsection{Topography}

The clavicle and the first metatarsal were clearly the most exposed bones in our study (Table 1) and in the literature [5] [33]. According to our knowledge, 45 floating clavicles and 17 floating first metatarsals were reported since Porral [9] and English [35]. The other floating bones were more exceptional. The explanation might be found in the mechanism and the joints stabilizers.

\subsubsection{Complications}

Associated fractures were common on the hip-joint [16], forearm [15] [27] [28] [29] and the tarsometatarsal joint [3] [6] [7] [8] [11].

All reported floating clavicle cases were displaced anteriorly at their sternoclavicular joint [1] [2] [3] [4] [5] [9] [33]. They did not represent any

Table 1. Reported cases of floating bones characteristics.

\begin{tabular}{|c|c|c|c|c|c|c|c|c|c|c|c|c|c|c|c|}
\hline \multirow{2}{*}{ 芒 } & \multirow[t]{2}{*}{$\stackrel{\varpi}{\infty}$} & \multirow{2}{*}{\multicolumn{2}{|c|}{ 品 䒕 }} & \multirow{2}{*}{ 㝏 } & \multicolumn{2}{|c|}{ 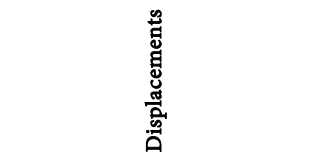 } & \multicolumn{3}{|c|}{ 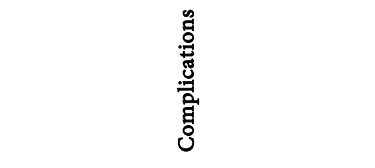 } & \multicolumn{2}{|c|}{ 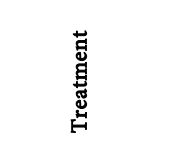 } & \multirow[t]{2}{*}{ 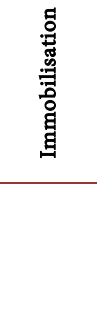 } & \multirow[t]{2}{*}{ 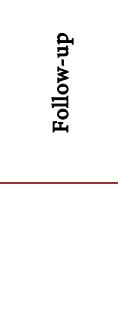 } & \multicolumn{2}{|c|}{ 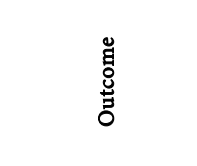 } \\
\hline & & & & & 胥 & 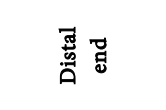 & 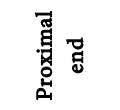 & 蛋㤩 & 壱 & 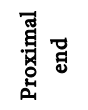 & 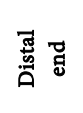 & & & 荣 & 氶 す \\
\hline Clavicle & $\mathrm{F}$ & 48 & $\mathrm{R}$ & $\begin{array}{l}\text { Axial loading } \\
\text { (RTA) }\end{array}$ & Anterior & Posterior & & & & $\begin{array}{c}\text { ORIF } \\
\text { (wires) }\end{array}$ & $\begin{array}{c}\text { ORIF } \\
\text { (wires) }\end{array}$ & Sling & 24 months & Excellent & Excellent \\
\hline Clavicle & M & 19 & $\mathrm{~L}$ & Fall (Sport) & Anterior & Posterior & & $\begin{array}{c}\text { Cutaneous } \\
\text { thread }\end{array}$ & & $\begin{array}{c}\text { ORIF } \\
\text { (wires) }\end{array}$ & $\begin{array}{l}\text { ORIF } \\
\text { (wires) }\end{array}$ & Sling & 72 months & Excellent & Excellent \\
\hline Clavicle & $\mathrm{F}$ & 40 & $\mathrm{R}$ & $\begin{array}{l}\text { Axial loading } \\
\text { (RTA) }\end{array}$ & Anterior & Posterior & & & $\begin{array}{l}\text { Thoracic } \\
\text { contusion }\end{array}$ & $\begin{array}{c}\text { ORIF } \\
\text { (wires) }\end{array}$ & $\begin{array}{c}\text { ORIF } \\
\text { (wires) }\end{array}$ & & 15 months & Excellent & Excellent \\
\hline $\begin{array}{c}\text { First } \\
\text { metatarsal }\end{array}$ & M & 25 & $\mathrm{~L}$ & $\begin{array}{l}\text { Axial loading } \\
\text { (RTA) }\end{array}$ & $\begin{array}{l}\text { Superior } \\
\text { (Dorsal) }\end{array}$ & $\begin{array}{c}\text { Inferior (Dorsal } \\
\text { MTPJ } \\
\text { dislocation) }\end{array}$ & & $\begin{array}{c}\text { Open } \\
\text { (plantar) }\end{array}$ & & OR & OR & $\begin{array}{c}\text { Plaster } \\
\text { (3 weeks) }\end{array}$ & 12 months & Excellent & Excellent \\
\hline $\begin{array}{c}\text { First } \\
\text { metatarsal }\end{array}$ & M & 28 & $\mathrm{~L}$ & $\begin{array}{l}\text { Axial loading } \\
\text { (RTA) }\end{array}$ & Supero-medial & $\begin{array}{c}\text { Lateral (Medial } \\
\text { MTPJ } \\
\text { dislocation) }\end{array}$ & & & $\begin{array}{c}\text { Brain } \\
\text { injury, M2 } \\
\text { fracture }\end{array}$ & $\begin{array}{l}\text { ORIF } \\
\text { (wires) }\end{array}$ & OR & $\begin{array}{c}\text { Plaster } \\
\text { (8 weeks) }\end{array}$ & 3 months & Excellent & Excellent \\
\hline $\begin{array}{c}\text { First } \\
\text { metatarsal }\end{array}$ & M & 53 & $\mathrm{R}$ & $\begin{array}{l}\text { Heavy loading } \\
\text { (WPA) }\end{array}$ & Supero-medial & $\begin{array}{c}\text { Lateral (Medial } \\
\text { MTPJ } \\
\text { dislocation) }\end{array}$ & & $\begin{array}{c}\text { Open } \\
\text { (medial) }\end{array}$ & $\begin{array}{c}\text { Brain } \\
\text { injury, M2 } \\
\text { fracture }\end{array}$ & $\begin{array}{l}\mathrm{CR}+ \\
\mathrm{PCF} \\
\text { (wire) }\end{array}$ & OR & $\begin{array}{c}\text { Plaster } \\
\text { (3 weeks) }\end{array}$ & 3 months & Excellent & Excellent \\
\hline Radius-Ulna & M & 33 & $\mathrm{R}$ & FFH & Posterior & $\begin{array}{c}\text { Anterior } \\
\text { (Dorsal RC } \\
\text { dislocation) }\end{array}$ & & $\begin{array}{l}\text { Distal radius } \\
\text { fracture }\end{array}$ & & $\mathrm{CR}$ & $\begin{array}{c}\text { Exofixa } \\
\text { tion }\end{array}$ & & 5 months & Excellent & Fair \\
\hline $\begin{array}{l}\text { Radius-Ulna- } \\
\text { Lunatum }\end{array}$ & M & 25 & $\mathrm{~L}$ & FFH & Posterior & $\begin{array}{c}\text { Anterior } \\
\text { (Dorsal PL } \\
\text { dislocation) }\end{array}$ & & & & $\mathrm{CR}$ & $\mathrm{CR}$ & $\begin{array}{c}\text { Plaster } \\
\text { (3 weeks) }\end{array}$ & $\begin{array}{l}\text { Lost of } \\
\text { view }\end{array}$ & & \\
\hline Femur & M & 65 & $\mathrm{R}$ & $\begin{array}{l}\text { Axial loading } \\
\text { (RTA) }\end{array}$ & Posterior & $\begin{array}{c}\text { Anterior } \\
\text { (Posterior knee } \\
\text { dislocation) }\end{array}$ & $\begin{array}{l}\text { Acetabular } \\
\text { fracture }\end{array}$ & $\begin{array}{c}\text { Cruciate } \\
\text { ligament tears }\end{array}$ & & CR & $\mathrm{CR}$ & $\begin{array}{l}\text { Traction } \\
\text { (3 weeks) }\end{array}$ & 18 months & Fair & Poor \\
\hline $\begin{array}{c}\text { First } \\
\text { Metacarpal }\end{array}$ & M & 43 & $\mathrm{~L}$ & Fall (WPA) & $\begin{array}{l}\text { Posterior } \\
\text { (Dorsal) }\end{array}$ & $\begin{array}{c}\text { Anterior } \\
\text { (Dorsal MCPJ } \\
\text { dislocation) }\end{array}$ & & & & $\begin{array}{l}\text { ORIF } \\
\text { (wires) }\end{array}$ & $\begin{array}{l}\text { ORIF } \\
\text { (wires) }\end{array}$ & & $\begin{array}{l}\text { Lost of } \\
\text { view }\end{array}$ & & \\
\hline $\begin{array}{l}\text { First Phalanx } \\
\text { (Index finger) }\end{array}$ & M & 30 & $\mathrm{~L}$ & $\begin{array}{l}\text { Machine } \\
\text { accident } \\
\text { (WPA) }\end{array}$ & Posterior & $\begin{array}{c}\text { Dorsal (Palmar } \\
\text { PIPJ } \\
\text { dislocation) }\end{array}$ & $\begin{array}{c}\text { Open } \\
\text { (Lateral) }\end{array}$ & $\begin{array}{c}\text { Open } \\
\text { (medial) }\end{array}$ & & $\begin{array}{c}\text { ORIF } \\
\text { (wires) }\end{array}$ & OR & Splint & $\begin{array}{l}\text { Lost of } \\
\text { view }\end{array}$ & & \\
\hline
\end{tabular}


mediastinal thread. Hand and foot dislocations are usually open dislocations [6] [12] [13] [22]. On extremities, the range of mobility is greater and the soft tissues around joints are fewer. It is commonly a skin opening from inside to outside (head of the first metatarsal). We found no post-operative complication. It is important to check pins and to remove them before six weeks.

\subsubsection{Treatment and Outcome}

First reported floating bones cases were treated conservatively [2] [4] [5] [9]. More recent authors preferred surgical management [3] [10] [11] [12] [13] [33]. We used more surgical management with good results. The advantage of surgical treatment is anatomic reduction, soft tissues stabilizers repairing, temporarily internal fixation and associated lesions management. The non-complicated floating humerus [18] [32], floating phalanx and floating femur [34] are exception of primary surgery.

\section{Conclusion}

The floating bone injury is still unknown and not well-described. Our study focused the nosology, the MOI, the clinical forms and the treatment of this double dislocation. It is important for any joint dislocation to check the other end of the dislocated bone to avoid missing a floating bone.

\section{Conflict of Interests}

The authors declare that they have no competing interests.

\section{Consent}

The patient and the families were informed that data from the case would be submitted for publication and provided their consent accordingly.

\section{Author's Contributions}

All the authors contributed of the writing of this manuscript and have read and approved the final version.

\section{References}

[1] Benabdallah, O. (1991) Bipolar Dislocation of Clavicle. Case Report. Revue de Chirurgie Orthopedique et Reparatrice De L'Appareil Moteur, 77, 263-266.

[2] Eni-Olotu, D.O. and Hobbs, N.J. (1997) Floating Clavicle-Simultaneous Dislocation of Both Ends of the Clavicle. Injury, 28, 319-320. https://doi.org/10.1016/S0020-1383(97)00009-0

[3] Dieme, C., Bousso, A., Sane, A., Sane, J.C., Niane, M., Ndiaye, A., Sy, M.H. and Seye, S. (2007) Bipolar Dislocation of the Clavicle or Floating Clavicle. A Report of 3 Cases. Chirurgie de la Main, 26, 113-116. https://doi.org/10.1016/j.main.2007.02.004

[4] Gearen, P.F. and Petty, W. (1982) Panclavicular Dislocation. Report of a Case. The Journal of Bone and Joint Surgery American Case Connector, 3, 454-455. https://doi.org/10.2106/00004623-198264030-00019 
[5] Jain, A.S. (1984) Traumatic Floating Clavicle. A Case Report. The Journal of Bone and Joint Surgery (British Volume), 66, 560-561.

[6] Leibner, E.D., Mattan, Y., Shaoul, J. and Nyska, M. (1997) Floating Metatarsal: Concomitant Lisfranc Fracture-Dislocation and Complex Dislocation of the First Metatarsophalangeal Joint. Journal of Trauma and Acute Care Surgery, 42, 549-552. https://doi.org/10.1097/00005373-199703000-00028

[7] Milankov, M., Miljkovic, N. and Popovic, N. (2003) Concomitant Plantar Tarsometatarsal (Lisfranc) and Metatarsophalangeal Joint Dislocations. Archives of Orthopaedic and Trauma Surgery, 123, 95-97. https://doi.org/10.1007/s00402-003-0477-0

[8] Trinquier, J.L., Filloux, J.F., Paul, H., Jarde, O. and Vives, P. (1995) Bipolar Dislocation of the First Metatarsal Bone. Acta Orthopaedica Belgica, 61, 238-241.

[9] Porral, A. (1831) Case Report of a Double Dislocation of the Right Clavicule Bone. Medical and Practical Surgery Journal, 2, 78-82.

[10] Jain, R. and Jain, S. (2006) The Floating First Metatarsal: A Case Report. The Journal of Foot \& Ankle Surgery, 45, 34-37.

https://doi.org/10.1053/j.jfas.2005.10.001

[11] Espiérrez, J.C., Martínez, Á.A., Herrera, A. and Panisello, J.J. (2003) The Floating Metatarsal: First Metatarsophalangeal Joint Dislocation with Associated Lisfranc Dislocation. Journal of Foot \& Ankle Surgery, 42, 309-311. https://doi.org/10.1016/S1067-2516(03)00308-9

[12] Dieme, C., Sane, A., Ngom, G., Sane, J., Ndiaye, A. And Seye, S. (2004) The Floating First Metatarsal: A Case Report. Médecine et Chirurgie du Pied, 20, 110-111. https://doi.org/10.1007/s10243-004-0025-9

[13] Dakouré, P.W.H., Soulama, M., Gandéma, S., Diallo, M. and Da, S.C. (2011) Floating First Metatarsal: A Case Report. Médecine et Chirurgie du Pied, 29, 94-97. https://doi.org/10.1007/s10243-013-0375-2

[14] Zejjari, H., Louaste, J., Chkoura, M. and Rachid, K. (2011) Floating Forearm: Case Report. Chirurgie de la Main, 30, 155-158. https://doi.org/10.1016/j.main.2011.02.002

[15] Najeb, Y., Essadki, B., Latifi, M. and Fikry, T. (2007) Bipolar Dislocation of Forearm: Elbow Dislocation and Transcapholunate Wrist Dislocation. Case Report. Chirurgie de la Main, 26, 62-64. https://doi.org/10.1016/j.main.2006.09.003

[16] Motsis, E., Pakos, E., Zaharis, K., Korompilias, A. and Xenakis, T. (2006) Concomitant Ipsilateral Traumatic Dislocation of the Hip and Knee Following High-Energy Trauma: A Case Report. Journal of Orthopaedic Surgery (Hong Kong), 14, 322-324. https://doi.org/10.1177/230949900601400317

[17] Vaseenon, T., Wongtriratanachai, P. and Laohapoonrungsee, A. (2010) Ipsilateral Anterior Hip Dislocation and Posterior Knee Subluxation: A Case Report. Journal of the Medical Association of Thailand, 93, 128-131.

[18] Suman, R.K. (1981) Simultaneous Dislocations of the Shoulder and the Elbow. Injury, 12, 438-438.

[19] Moore, J.R., Webb, C.A. and Thompson, R.C. (1978) A Complete Dislocation of the Thumb Metacarpal. Journal of Hand Surgery (American Volume), 3, 547-549. https://doi.org/10.1016/S0363-5023(78)80004-5

[20] Khodadadyan, C., Hoffmann, R., Moazami-Goudarzi, Y. and Südkamp, N.P. (1995) Double Dislocation of the Fifth Metacarpal. Journal of Hand Surgery (British Volume), 20, 253-254. https://doi.org/10.1016/S0266-7681(05)80064-6 
[21] Ibrahim, S. and Noor, M.A. (1993) Simultaneous Dislocations of the Carpometacarpal and Metacarpophalangeal Joints of the Thumb. Injury, 24, 343-344. https://doi.org/10.1016/0020-1383(93)90062-B

[22] Gerard, F., Tropet, Y. and Obert, L. (1999) Trapezo-Metacarpal and MetacarpoPhalangeal Dislocation of the Thumb Associated with a Carpo-Metacarpal Dislocation of the Four Fingers. Annales de Chirurgie de la Main et du Membre Supérieur, 18, 205-208. https://doi.org/10.1016/S1153-2424(99)80007-7

[23] Kulshreshtha, R., Venu, K., Qureshi, F. and Lahoti, O. (2005) Divergent Dislocation of Elbow with Ipsilateral Distal Radioulnar Joint Dislocation in a Gymnast. European Journal of Trauma, 31, 495-498. https://doi.org/10.1007/s00068-005-1039-7

[24] Hey, H.W., Huh Lau, B.P., Thambiah, J., Khong, K.S. and Murphy, D.P. (2013) "Floating Fibula" Secondary to Traumatic Dislocation of the Ankle Joint, Ankle Syndesmosis, and the Proximal Tibiofibular Joint. A Case Report. The Journal of Bone and Joint Surgery American Case Connector, 3, 101-105.

[25] Unay, K., Ozkan, K., Ugutmen, E., Ozkan, F.U., Eren, A. and Bilsel, K. (2008) Simultaneous Ipsilateral Proximal Interphalangeal and Metacarpophalangeal Dislocation of the Fifth Phalanx: A Case Report. Cases Journal, 3, 208. https://doi.org/10.1186/1757-1626-1-208

[26] Bartels, M. (1874) Traumatic Dislocation. Archives de Chirurgie in French, Surgery archives, 16, 645.

[27] Dodd, C.A. (1987) Triple Dislocation in the Upper Limb. Journal of Trauma-Injury Infection \& Critical Care, 27, 1307. https://doi.org/10.1097/00005373-198711000-00019

[28] Sivan, M., Davies, N., Archibald, C. and Pailthorpe, C. (2005) An Unusual Combination of Radiocarpal Fracture Dislocation, Scaphoid Fracture and Posteromedial Elbow Dislocation. Injury Extra, 36, 312-315. https://doi.org/10.1016/j.injury.2004.12.057

[29] Chen, W.S. (1994) Concurrent Perilunate Dislocation in Patients with Elbow Dislocation: Case Reports. Journal of Trauma-Injury Infection \& Critical Care, 37, 504-507. https://doi.org/10.1097/00005373-199409000-00029

[30] Ovadia, D., Steinberg, E.L., Mozes, G. and Menahem, A. (2001) "Floating Tibia-Talus Complex"-An Ipsilateral Dislocation of the Knee and the Subtalar Joint in an Elderly Patient: A Case Report and Review of the Literature. Journal of Foot and Ankle Surgery, 40, 113-115. https://doi.org/10.1016/S1067-2516(01)80054-5

[31] Moonen, A., Tilman, P., van der Ent, F. and Verburg, A. (2006) Obturator Dislocation of the Hip with Associated Open Book Fracture of the Pelvis. Injury Extra, 37, 319-321. https://doi.org/10.1016/j.injury.2006.02.017

[32] Essoh, J.B.S., Kodo, M., Traoré, A. and Lambin, Y. (2005) Ipsilateral Dislocation of the Shoulder and Elbow: A Case Report. Nigerian Journal of Surgical Research, 7, 319-320.

[33] Arenas, A., Pampliega, T. and Iglesias, J. (1993) Surgical Management of Bipolar Clavicular Dislocation. Acta Orthopædica Belgica, 59, 202-202.

[34] Kamboj, P., Kundu, Z., Sangwan, S. and Walecha, P. (2007) Ipsilateral Anterior Hip and Posterior Knee Dislocation with Common Peroneal Nerve Palsy: A Particular mode of Trauma in a Case. The Internet Journal of Orthopedic Surgery, 6.

[35] English, T.A. (1964) Dislocations of the Metatarsal Bone and Adjacent Toe. The Journal of Bone and Joint Surgery. British Volume, 46, 700-704. 
[36] Sommer, C., Leutenegger, A. and Rüedi, T. (1998) The Floating Joint Injury of the Lower and Upper Extremity: Epidemiology, Therapy and Results in 40 Extremities. Swiss Surgery, 4, 163-169. 